\title{
The present problems of plant protection in Poland Part I. History, Science, Education
}

\author{
Aktualne problemy ochrony roślin w Polsce \\ Część I. Historia, Nauka, Edukacja
}

\author{
Stefan Pruszyński ${ }^{1}$, Adam Błochowiak ${ }^{2}$
}

\section{Summary}

The most important issues of plant protection in Poland in the field of science and education that need an urgent solution are: increase in financial support for the development of research along with establishment of new research programmers including integrated plant protection issues and their coordination on national level, amending changes at all levels of agricultural education aiming in batter preparation of gradiuates serving in advisory services and farmers in the implementation of integrated plant protection (IPP).

Key words: Poland, plant protection, history, research programmers, education

\section{Streszczenie}

Na podstawie dokonanego przeglądu historii ochrony roślin w Polsce po II Wojnie Światowej, stanu badań oraz edukacji w zakresie ochrony roślin, za najważniejsze problemy wymagające pilnego rozwiązania należy uznać: wzrost nakładów na badania naukowe z uwzględnieniem tworzenia nowych programów badawczych uwzględniających tematykę integrowanej ochrony roślin oraz ich koordynację na krajowym poziomie, dokonanie zmian w programach nauczania na wszystkich poziomach edukacji rolniczej z celem lepszego przygotowania absolwentów mogących pełnić funkcje doradcze dla doradców rolniczych i producentów rolnych w upowszechnianiu integrowanej ochrony roślin.

Słowa kluczowe: Polska, ochrona roślin, historia, programy badawcze, edukacja

\footnotetext{
Staffa 9, 60-194 Poznań

s.pruszyński@iorpib.poznan.pl

${ }^{2}$ Wojewódzki Inspektorat Ochrony Roślin i Nasiennictwa

Grunwaldzka 250 B, 60-166 Poznań

adam.blochowiak@poczta.fm
} 


\section{Wstęp / Introduction}

Ochrona roślin jest obecnie stałym elementem technologii produkcji rolniczej i ogrodniczej odgrywając podstawową rolę $\mathrm{w}$ niedopuszczaniu do powstania lub ograniczaniu strat powodowanych w roślinach uprawnych przez choroby, szkodniki i chwasty. Jednocześnie ochrona roślin jest dziedziną niezwykle dynamicznie rozwijającą się, w której w ciągu ostatnich 60 . lat zachodzą najczęstsze zmiany. Sa one wymuszane pojawem nowych gatunków agrofagów lub zmianą ważności gospodarczej już wcześniej występujących, zmianą asortymentu środków ochrony roślin i zmieniającymi się możliwościami metod ochrony, wynikami badań naukowych, wprowadzaniem nowych odmian roślin uprawnych, zwiększającymi się wymaganiami konsumentów, potrzebą ochrony środowiska czy wreszcie koniecznością podporządkowania się przepisom krajowym i międzynarodowym. Wszystko to narzuca obowiązek stałego śledzenia zachodzących zmian oraz ciagłego uaktualniania obowiazzujących zaleceń. Tak jest również obecnie, gdy wdrażana jest Strategia Zrównoważonego Stosowania Pestycydów oraz należy się przygotować do powszechnego obowiązku wprowadzenia integrowanych programów ochrony.

\section{Krótka historia ochrony roślin w Polsce po II Wojnie Światowej / Short history of the plant protection in Poland after Second Word War}

Cofnięcie się w czasie i prześledzenie rozwoju ochrony roślin $\mathrm{w}$ Polsce $\mathrm{i}$ zachodzących $\mathrm{w}$ niej zmian będzie niezwykle pomocne w omówieniu aktualnych problemów i zadań tejże ochrony.

Nalot stonki ziemniaczanej (Leptinotarsa decemlineata Say.) bezpośrednio po II Wojnie Światowej i zagrożenie, jakie ten szkodnik stanowił dla uprawianych na areale ponad $2 \mathrm{mln}$ ha ziemniaków wymusił podjęcie przez władze wielu istotnych decyzji. W 1947 roku podjęto w Zakładach Chemicznych „Azot” w Jaworznie produkcje DDT, a następnie metoksychloru $\mathrm{i}$ innych substancji czynnych (s.cz.) (Pruszyński i Moszczyński 1992). W roku 1955 polski przemysł produkował $2000 \mathrm{t}$ s.cz. i produkcja ta zwiększyła się do roku 1970 do 12000 t s.a. W następnych latach stworzono preferencje dla importu środków ochrony roślin (ś.o.r.) i to dotowanego potrójnie poprzez przydział tanich dewiz, niskie cło i dotowanie cen sprzedaży. W tej sytuacji przemysł, gdy sprzedaż ś.o.r. była poniżej kosztów produkcji, interesował się głównie importem, formulacją i konfekcjonowaniem nie podejmując własnej produkcji. Pozytywnym efektem takiej polityki był natomiast szeroki dostęp producentów rolnych do tanich i nowoczesnych ś.o.r.

Należy podkreślić, że pomimo takiej sytuacji w Polsce nigdy nie miało miejsca masowe stosowanie ś.o.r. i ich zużycie było znacznie niższe $\mathrm{w}$ porównaniu do rozwiniętych krajów europejskich. W latach 1975 i 1988 w ochronie zbóż uprawianych na powierzchni 8,1 do $8,4 \mathrm{mln}$ ha zaprawianie ziarna wykonywano w stosunku do 54 i 51\% wysiewanego ziarna, zwalczania chorób w okresie wegetacji w ogóle nie stosowano w roku 1975, a w roku 1988 zabiegami objęto $12 \%$ ogółu areału. Zwiększył się areał zwalczania chwastów, który w roku 1975 objął $32 \%$ upraw zbóż, a w roku 1988 już 63\%. Dalsze obniżenie stosowania ś.o.r. miało miejsce po zmianach gospodarczych i ekonomicznych przełomu lat 90 . ubiegłego wieku, kiedy to nastapił nieproporcjonalny wzrost cen ś.o.r. do cen produktów rolnych. W tabeli 1. przedstawiono zmianę relacji cen ś.o.r. w latach 1989-2001, w odniesieniu do cen produktów rolnych, a konsekwencją tego było dalsze obniżenie areału chronionego i w roku $1991 \mathrm{w}$ uprawie zbóż zaprawiono 38\% ziarna, choroby zwalczano w 8\% upraw, a chwasty w $40 \%$ zasiewów. W następnych latach nastapiła stabilizacja cen ś.o.r . (tab. 2), a wstapienie Polski do Unii Europejskiej oraz wprowadzone dotacje spowodowały intensyfikacje produkcji rolnej i związany $z$ tym wzrost zużycia chemicznych ś.o.r., który wynosi obecnie około $1,84 \mathrm{~kg}$ s.cz./ha (Surawska i Kołodziejczyk 2006), wahając się od $0,35 \mathrm{~kg}$ s.cz./ha w ochronie żyta do $11,027 \mathrm{~kg}$ s.cz./ha w ochronie jabłoni (Stobiecki i wsp. 2010). Omawiając podporządkowanie się przez Polskę zaleceniom strategii zrównoważonego stosowania pestycydów, korzystnym dla naszego kraju jest, że nie ma potrzeby dążenia do ograniczania stosowania chemicznych ś.o.r., a raczej należy dążyć do racjonalizacji oraz prawidłowego ich stosowania.

Tabela 1. Zmiana relacji cen środków ochrony w Polsce, w latach 1989-2001, w odniesieniu do cen produktów rolnych (Pruszyński 2008) Table 1. Changes in retail prices of plant protection products, in relation to agricultural product prices, in 1989-2001 (Pruszyński 2008)

\begin{tabular}{l|c|c|c|c}
\hline \multirow{2}{*}{$\begin{array}{c}\text { Środek ochrony roślin } \\
\text { Plant protection product }\end{array}$} & \multirow{2}{*}{$\begin{array}{c}\text { Uprawa } \\
\text { Crop }\end{array}$} & \multicolumn{2}{|c}{$\begin{array}{c}\text { Ilość produktu [dt] jako odpowiednik środka ochrony roślin [kg lub l] } \\
\text { Agricultural product quantity [dt] equivalent } \\
\text { for plant protection products [kg or l] }\end{array}$} \\
\cline { 2 - 5 } Chwastox DF & $\begin{array}{c}\text { pszenica } \\
\text { wheat }\end{array}$ & 0,05 & 1991 & 2001 \\
\hline Decis 2,5 EC & $\begin{array}{c}\text { pszenica } \\
\text { wheat }\end{array}$ & 0,26 & 1,70 & 0,30 \\
\hline Siarkol K 85 WP & $\begin{array}{c}\text { pszenica } \\
\text { wheat }\end{array}$ & 0,016 & 0,23 & 1,29 \\
\hline Decis 2,5 EC & $\begin{array}{c}\text { rzepak ozimy } \\
\text { winter rape }\end{array}$ & 0,25 & 1,06 & 0,14 \\
\hline Fusilade Super 125 EC & $\begin{array}{c}\text { burak ćwikłowy } \\
\text { red beet }\end{array}$ & 0,78 & 8,00 & 0,94 \\
\hline
\end{tabular}


Tabela 2. Relacje cen detalicznych środków ochrony roślin w latach 2000-2006 (Mieczkowski i Pruszyński 2008)

Table 2. Changes in retail prices of plant protection products in 2000-2006 (Mieczkowski i Pruszyński 2008)

\begin{tabular}{l|c|c|c|c|c|c|c}
\hline \multicolumn{1}{c|}{$\begin{array}{c}\text { Wyszczególnienie } \\
\text { Specyfication }\end{array}$} & 2000 & 2001 & 2002 & 2003 & 2004 & 2005 & 2006 \\
\hline $\begin{array}{l}\text { Srodki ochrony roślin* } \\
\text { Plant protection products* }\end{array}$ & 104,3 & 102,1 & 100,5 & 99,4 & 101,9 & 101,7 & 100,8 \\
\hline
\end{tabular}

*rok poprzedni - $100 \%$ - previous year - $100 \%$

W analizowanym okresie miały miejsce ważne wydarzenia i dynamiczne zmiany w nauce o ochronie roślin.

W roku 1951 powołany został Instytut Ochrony Roślin z siedzibą w Puławach, przeniesiony w 1956 roku do Poznania. Na terenie kraju tworzono Wyższe Szkoły Rolnicze z Katedrami Ochrony Roślin, Entomologii, Fitopatologii oraz Techniki Ochrony Roślin, co miało pozytywny wpływ na rozwój badań, ale przede wszystkim na przygotowanie kompetentnych specjalistów z zakresu ochrony roślin. Ich obecność w produkcji rolniczej pozwoliła na prawidłową realizację zadań w zmieniającej się ochronie roślin.

Za decyzję o podstawowym znaczeniu dla rozwoju nauki w Polsce należy uznać ustalenie przez Rząd Problemów Węzłowych, a więc tematów o istotnym znaczeniu dla rozwoju gospodarki w realizacji, których uczestniczyły jednostki naukowe z całego kraju.

Instytut Ochrony Roślin był koordynatorem 4 kolejnych 5-letnich Problemów Węzłowych (pierwszy rozpoczął się w 1967 roku) oraz w latach 1986-1991 Centralnego Programu Badawczo-Rozwojowego. Był to dobry okres dla nauki ochrony roślin, kiedy kompleksowo, w każdym programie uczestniczyło ponad 20 jednostek, rozwiązywano najważniejsze problemy. Początek lat 90. przyniósł nie tylko znaczne ograniczenie nakładów na naukę, ale także likwidację koordynacji badań. Negatywne konsekwencje tych decyzji są widoczne do chwili obecnej.

W nowym systemie finansowania do realizacji zaczęła trafiać większa liczba niewielkich projektów badawczych, nie zawsze o wymaganym znaczeniu dla nauki i praktyki ochrony roślin.

W zakresie ustawodawstwa w Polsce przez długi okres obowiązywała Ustawa o ochronie roślin z 1961 roku (Ustawa 1961). Jednym z ważnych zapisów tej Ustawy było wprowadzenie obowiązku uzyskiwania zezwoleń (rejestracji) na dopuszczenie do obrotu handlowego chemicznych ś.o.r. Zarządzenie Ministra Rolnictwa w tej sprawie ukazało się 22 kwietnia 1965 roku i już w tym samym roku Ministerstwo Rolnictwa ogłosiło pierwszy wykaz 190 środków dopuszczonych do stosowania w ochronie upraw w Polsce.

Kolejnym aktem prawnym była Ustawa o ochronie roślin z 1995 roku (Ustawa 1995), a jej treść wniosła wiele istotnych i ważnych zmian $\mathrm{w}$ funkcjonowaniu ochrony roślin w Polsce, w tym utworzenie Inspekcji Ochrony Roślin. W omawianej Ustawie, a także kolejnych uchwalanych $\mathrm{w}$ następnych latach, ważnym elementem było implementowanie do polskiego ustawodawstwa zapisów obowiązujących w Unii Europejskiej.

Uchwała Rady Ministrów Nr 64/70 z dnia 18 maja 1970 roku w sprawie organizacji badań w zakresie toksy- kologii i biologicznego stosowania pestycydów oraz kontroli ich pozostałości w żywności i środowisku życia człowieka, wprowadziła ogólnokrajowy monitoring analiz na pozostałości ś.o.r. oraz doprowadziła do wycofania ze stosowania w polskiej ochronie roślin, w opinii wielu osób przedwcześnie: lindanu, zapraw rtęciowych, DDT, związków dienowych, chlorowanych kamfenów, nitrofenu, cinebu i innych. Wycofano także ze stosowania formulacje pyliste oraz wprowadzono wyrywkową kontrole jakości ś.o.r. Dalsze działania w tym kierunku najlepiej oddaje artykuł z Ustawy o ochronie roślin z 2003 roku (Ustawa 2003), który stanowi, że „Ustawa ureguluje sprawy zapobiegania zagrożeniom dla zdrowia człowieka, zwierząt oraz środowiska, które mogą powstać w wyniku obrotu i stosowania środków ochrony roślin". Do wyprzedzających ustawodawstwo wielu krajów należą zapisy wprowadzające obowiązkowe szkolenia wykonawców zabiegów ochrony roślin oraz techniczne przeglądy opryskiwaczy.

Bardzo ważną rolę we właściwym rozwoju ochrony roślin spełniają pracownicy, których tradycyjnie określa się mianem „służby ochrony roślin”, a którzy obecnie po wejściu w życie ustawy z 1995 roku stali się pracownikami Państwowej Inspekcji Ochrony Roślin i Nasiennictwa. Historię oraz zmiany w strukturze organizacyjnej służby ochrony roślin przedstawiła Stachowicz (2000), a znaczenie służby ochrony roślin i potrzebę jej przygotowania do wypełniania obowiązków szeroko omówił Prof. Władysław Węgorek (Węgorek 1972).

Utworzenie na mocy ustawy z 1995 roku Państwowej Inspekcji Ochrony Roślin zmieniło całkowicie charakter pracy i zakres obowiązków pracowników Inspekcji.

Inspekcja zgodnie $\mathrm{z}$ wymaganiami Międzynarodowej Konwencji Ochrony Roślin stała się jednostką kontrolującą stan fitosanitarny upraw oraz stosowanie ś.o.r. bez obowiązku prowadzenia działalności doradczej. Było to bardzo niekorzystne dla funkcjonowania ochrony roślin, szczególnie mając na uwadze fakt, że do pełnienia obowiązków doradczych nie byli przygotowani pracownicy Ośrodków Doradztwa Rolniczego. Rola i zadania Państwowej Inspekcji Ochrony Roślin i Nasiennictwa, a także doradztwo $\mathrm{w}$ zakresie ochrony roślin zostaną przedstawione w części drugiej opracowania.

Przedstawione przykłady działań w zakresie ochrony roślin w Polsce potwierdzają prawidłowy rozwój tego obszaru działalności naukowej i praktycznej w naszym kraju, jednakże zobowiązania, jakie wynikają z przynależności Polski do Unii Europejskiej oraz zmiany zachodzące w ochronie roślin wymagają podejmowania kolejnych działań 


\section{Nauka / Science}

Polska dysponuje silnym i bogatym zapleczem naukowym w obszarze ochrony roślin, a potwierdzeniem takiego stanu jest fakt, że w przygotowaniu prezentacji na kolejne Sesje Naukowe Instytutu Ochrony Roślin uczestniczy rokrocznie ponad 650 autorów reprezentujących około 75 różnych placówek naukowych (Wolny i wsp. 2010).

Również w odbywających się w drugiej połowie 2011 roku wyborach do Komitetu Ochrony Roślin Polskiej Akademii Nauk ponad 130 samodzielnych pracowników naukowych zadeklarowało chęć uczestniczenia w wyborach, potwierdzając tym samym swoje zaangażowanie w badaniach na rzecz ochrony roślin.

W Polsce publikowane są również uznane w kraju i zagranicą wydawnictwa naukowe: Journal of Plant Protection Research, Phytopathologia Polonica oraz Progress in Plant Protection/Postępy w Ochronie Roślin.

Niejednoznaczna jest jednak odpowiedź na pytanie: czy ten duży zespół ludzi zabezpiecza potrzeby ochrony roślin, gwarantuje jej rozwój i czy spełnia oczekiwania szeroko rozumianej praktyki?

$\mathrm{Z}$ jednej bowiem strony polski rolnik i ogrodnik miał zawsze dostęp do drukowanych regularnie Programów ochrony roślin rolniczych i ogrodniczych oraz do większości nowych ś.o.r. rejestrowanych w Polsce i włączanych do zaleceń ochrony poszczególnych upraw. Nie odbiegały one od podobnych zaleceń opracowywanych w krajach Europy Zachodniej. Z pomocy nauki bardzo często korzystają producenci szukający porady czy oceny zagrożenia. Jednostki naukowe spełniają też ważną rolę we wdrażaniu i upowszechnianiu nowych technologii czy metod ochrony, a także poprzez organizowanie konferencji i szkoleń bezpośrednio przekazują uzyskiwane wyniki.

$\mathrm{Z}$ drugiej jednak strony rolę nauki należy postrzegać znacznie szerzej. Nie jest to tylko rozwiązywanie bieżących problemów, ale także, a może nawet przede wszystkim, tworzenie naukowych podstaw dla przyszłego rozwoju ochrony roślin. Zadanie to jest szczególnie aktualne i ważne obecnie, gdy w przeciagu dwu lat przyjdzie nam przygotować warunki do powszechnego wprowadzenia integrowanej ochrony roślin przez rolników i ogrodników.

I tu sytuacja jest już znacznie trudniejsza, a u jej podstaw leżą dwie przyczyny.

Pierwsza to niskie nakłady na naukę i ograniczony wpływ Ministerstwa Rolnictwa i Rozwoju Wsi na podział środków. Druga to brak koordynacji badań i zatwierdzonych dużych programów badawczych, które skupiałyby większe grupy uczonych i większą liczbę jednostek.

$\mathrm{Na}$ zdrowotność upraw i na populacje organizmów szkodliwych ma wpływ wiele czynników: racjonalna gopodarka składnikami pokarmowymi, odmianowa odporność na choroby i szkodniki, oddziaływanie ś.o.r. na ludzi i środowisko, a także ekonomiczne aspekty stosowania zabiegów ochrony roślin. Wymaga to prowadzenia międzydyscyplinarnych i międzyinstytucjonalnych badań.

Do przeszłości należą czasy Problemów Węzłowych i Centralnych Programów Badawczych, w ramach których W realizację zadania zaangażowanych było ponad 20 jed- nostek naukowych kompleksowo rozwiązujących postawiony cel, a funkcji tych programów nie przejęły i ze względów formalnych nie mogą przejąć Programy Wieloletnie, ponieważ ich zadaniem jest przede wszystkim realizacja zadań o charakterze służb publicznych oraz ich główni wykonawcy w niewielkim stopniu uwzględniają udział w nich większej liczby jednostek naukowych.

Sytuacja ta, charakterystyczna zresztą dla obecnej organizacji badań naukowych w Polsce musi ulec zmianie i oczekiwać należy większej aktywności jednostek naukowych $\mathrm{w}$ przygotowywaniu wniosków na realizację dużych programów badawczych, a od Ministerstwa Rolnictwa i Rozwoju Wsi oraz Głównego Inspektoratu Ochrony Roślin i Nasiennictwa bardzo zdecydowanego poparcia dla realizacji tych wniosków. Z żalem należy podkreślić, że przygotowany przez Instytut Ochrony Roślin - Państwowy Instytut Badawczy przy współudziale Instytutu Uprawy Nawożenia i Gleboznawstwa - Państwowego Instytutu Badawczego, Instytutu Hodowli i Aklimatyzacji Roślin - Państwowego Instytutu Badawczego, Instytut Sadownictwa i Kwiaciarstwa oraz Instytut Warzywnictwa (obecnie Instytut Ogrodnictwa) projekt na opracowanie Platformy Informatycznej w zakresie integrowanej ochrony roślin nie uzyskał środków na jego realizację.

\section{Edukacja / Education}

W dniu 8 grudnia 2010 roku Podsekretarz Stanu w Ministerstwie Rolnictwa i Rozwoju Wsi, Pan Marian Zalewski skierował do szkolnictwa wyższego pismo, w którym informował o obowiązku zapewnienia wszystkim użytkownikom ś.o.r. dostępu do odpowiednich szkoleń prowadzonych przez podmioty wyznaczone przez właściwe organy.

Pan Podsekretarz zadał też pytanie: na ile obowiązujące obecnie programy nauczania stanowią podstawę do pełnienia usług doradczych w zakresie ochrony roślin oraz prowadzenia szkoleń $\mathrm{w}$ zakresie integrowanej ochrony roślin przez absolwentów wydziałów rolniczych, ogrodniczych, leśnych i pokrewnych szkół rolniczych?

W dniu 16 lutego 2011 roku po zapoznaniu się z pismem Podsekretarza Stanu swoje stanowisko przygotował i przedstawił Komitet Ochrony Roślin Polskiej Akademii Nauk (KOR PAN) (Stanowisko 2011). Należy przypomnieć, że Komitety Naukowe Polskiej Akademii Nauk są demokratycznie wybieranym zespołem pracowników naukowych reprezentujących daną dyscyplinę lub specjalizację naukową $\mathrm{i}$ rekrutujących się $\mathrm{z}$ różnych grup jednostek naukowych w kraju (szkolnictwo wyższe, Instytuty Polskiej Akademii Nauk, Instytuty Badawcze).

Poniżej prezentujemy obszerne fragmenty stanowiska KOR PAN, które nie tylko mogą stanowić podstawę do dyskusji, ale przede wszystkim przedstawiają konkretne propozycje rozwiązań.

Ze względu na obowiązujące wymogi formalne nabycia uprawnień doradcy, przy obecnej strukturze planów i programów nauczania na uczelniach rolniczych, spełnienie szczegółowych wymagań Załącznika II do Dyrektywy 2009/128/WE wydaje się niemal niemożliwe. 
Potrzeba w tym celu podwojenia liczby godzin zajęć ze studentami z przedmiotów wymienionych przez Ministerstwo Rolnictwa i Rozwoju Wsi.

W związku z tym Komitet Ochrony Roślin zwraca się do Rektorów, członków Senatów, Dziekanów i przedstawicieli Rad Wydziałów o krytyczną analizę programów nauczania i ich dostosowanie do wymogów Dyrektywy 2009/128/WE. Komitet postuluje rozszerzenie programów obecnie zatwierdzonych specjalizacji i/lub specjalności i zwraca uwagę na korzyści powołania specjalności (Integrowanej) Ochrony Roślin dla kształcenia światłych specjalistów zarówno do udoskonalenia istniejących zaleceń, jak i wdrażania integrowanej ochrony w Polsce.

Zdaniem Komitetu właściwą podstawą takiego działania byłoby porozumienie między Ministrem Rolnictwa i Rozwoju Wsi a Ministrem Nauki i Szkolnictwa Wyższego $\mathrm{W}$ sprawie włączenia do programów nauczania odpowiednich treści we właściwej liczbie godzin zajęć. Przykładem (niestety odosobnionym) takiej praktyki jest specjalność „Agroekologia i ochrona roślin” (w ramach kierunku Ogrodnictwo), funkcjonująca na Uniwersytecie Rolniczym w Krakowie od blisko 10 lat, w porozumieniu z Wojewódzkim Inspektoratem Ochrony Roślin i Nasiennictwa.

Widocznym efektem pisma Podsekretarza Stanu Mariana Zalewskiego oraz Stanowiska Komitetu Ochrony Roślin były pozytywne zmiany $\mathrm{w}$ programie nauczania ochrony roślin w Uniwersytetach Przyrodniczych w Lublinie oraz we Wrocławiu.

Odrębnym problemem jest przygotowanie programów i jednostek do prowadzenia szkolenia $\mathrm{z}$ zakresu integrowanej ochrony roślin dla wszystkich grup zawodowych związanych $\mathrm{z}$ dystrybucją i stosowaniem ś.o.r.

Obowiązek odbywania szkoleń przez użytkowników ś.o.r. oraz oddzielnie osób zajmujących się konfekcjonowaniem, dystrybucją i sprzedażą tych środków wprowadziła w Polsce Ustawa o ochronie roślin uprawnych z 1995 roku, a prowadzącymi szkolenia są jednostki upoważnione przez właściwego wojewódzkiego inspektora ochrony roślin.

Obecnie zgodnie z Art. 5. Dyrektywy 2009/128/WE wszystkie państwa członkowskie są zobowiązane zapewnić dostęp do odpowiednich szkoleń wszystkim użytkownikom ś.o.r. Tematy szkoleń zostały przedstawione w Załączniku I do Dyrektywy i obejmują one zakres nieporównywalnie większy od obowiązujących dotychczas programów.

Wystarczającym będzie zacytowanie p. 4. Załącznika I, który podaje następujący zakres tematyczny: „Podstawowa wiedza z zakresu strategii i technik integrowanej ochrony roślin, strategii i technik integrowanej produkcji, zasad rolnictwa ekologicznego, metod biologicznego zwalczania szkodników, informacje na temat ogólnych zasad i wytycznych $\mathrm{w}$ zakresie integrowanej ochrony roślin dla poszczególnych upraw i sektorów".

Należy pamiętać, że to producent rolny i ogrodniczy będzie najważniejszą postacią we wdrożeniu integrowanej ochrony roślin i dla wielu definicją integrowanej ochrony roślin jest prawidłowe przygotowanie $\mathrm{i}$ wiedza producenta rolnego (Dąbrowski 2011).

W związku z powyższym, przygotowanie programów szkoleń, jednostek je prowadzących oraz zapewnienie ich odbycia przez wszystkich użytkowników ś.o.r. jest jednym $\mathrm{z}$ najważniejszych zadań $\mathrm{w}$ realizacji programu Zrównoważonego Stosowania Pestycydów i wdrożenia zasad integrowanej ochrony roślin.

\section{Podsumowanie / Summation}

Wybierając aktualne problemy ochrony roślin w Polsce skupiono się na tych nie tylko najważniejszych, tj. historii, nauce $\mathrm{i}$ edukacji, ale również mających istotne znaczenie w przygotowaniu polskiej produkcji roślinnej do wprowadzania z dniem 1 stycznia 2014 roku integrowanej ochrony roślin.

Znacznego postępu można oczekiwać od polskiej nauki. Posiadające bogate zaplecze laboratoryjne oraz dużą grupę specjalistów jednostki naukowe mogą podjąć się, szczególnie przy dobrze ustalonej koordynacji, rozwiązania wielu istotnych problemów. Należy jednak oczekiwać zaangażowania Ministra Rolnictwa i Rozwoju Wsi, Ministra Nauki i Szkolnictwa Wyższego oraz Głównego Inspektoratu Inspekcji Ochrony Roślin i Nasiennictwa w rozwiązaniu problemów finansowych jednostek naukowych oraz poparcia realizacji zgłaszanych programów badawczych.

Bardzo ważna role do odegrania maja Uniwersytety Przyrodnicze, Uniwersytet Rolniczy i inne jednostki szkolnictwa wyższego prowadzące zajęcia $\mathrm{z}$ zakresu ochrony roślin. Dostosowanie programów nauczania odpowiadających potrzebom przygotowania absolwentów gotowych do doradztwa $\mathrm{i}$ upowszechniania integrowanej ochrony roślin jest naprawdę wymogiem chwili. Dobrze przygotowani, energiczni i zaangażowani w swą pracę specjaliści ochrony roślin zadecyduja o udanym wprowadzeniu integrowanej ochrony roślin.

Jako trudną i wymagającą dużego zaangażowania należy uznać potrzebę przygotowania szkoleń dla olbrzymich grup rolników. Będzie to duże wyzwanie, ale konieczne do podjęcia.

Tak, jak pisano wcześniej, to wiedza i przygotowanie rolnika zadecydują o sukcesie wdrożenia integrowanej ochrony i na to przygotowanie należy położyć szczególny nacisk.

Integrowana ochrona roślin jest gwarantem uzyskiwania wysokich plonów o dobrej jakości, ale wymaga od producenta dobrego przygotowania, często większych nakładów i właściwego podejścia. Jednak warto, bo integrowana ochrona roślin jest optymalnym rozwiązaniem przyszłościowym i źle by się stało, gdyby jej wdrożenie miało charakter tylko formalny. 


\section{Literatura / References}

Dąbrowski Z.T. 2011. Up - dating on integrated pest management in Poland. p. 17-18. Conference „Sustainable use of pesticides and integrated pest management in East-Central Europe and the Baltics”. Poland, Radzików, 4-6 September 2011, 115 ss..

Mieczkowski J., Pruszyński S. 2008. Rynek środków ochrony roślin. s. 10-14. W: „Rynek Środków Produkcji i Usług dla Rolnictwa. Stan i Perspektywy. IERiGŻ - PIB 33, 55 ss.

Pruszyński S. 2008. Stan obecny i przewidywane kierunki zmian w ochronie roślin do roku 2020. Ekspertyza dla IUNG - PIB, Puławy, 49 ss.

Pruszyński S., Moszczyński W. (red.). 1992. Produkcja i dystrybucja środków ochrony roślin. Raport o stanie i potrzebach ochrony roślin w Polsce. Inst. Ochr. Roślin, Poznań, 70 ss.

Stanowisko Komitetu Ochrony Roślin Polskiej Akademii Nauk dotyczące przygotowania zasobów ludzkich do wdrażania Dyrektywy Parlamentu Europejskiego i Rady 2009/128/WE z dnia 27.02.2009 r. ustanawiającej ramy wspólnotowego działania na rzecz Zrównoważonego Stosowania Pestycydów. Warszawa, $2011 \mathrm{r}$.

Stachowicz T. 2000. Historia Służby Ochrony Roślin oraz obecne miejsce inspekcji ochrony roślin w upowszechnianiu postępu i doradztwie. Prog. Plant Prot./Post. Ochr. Roślin 40 (1): 308-314.

Stobiecki S., Pruszyński S., Śliwiński W. 2010. Tworzenie programów redukcji ryzyka poprzez systematyczne badanie zagrożeń we wszystkich obszarach ochrony roślin. s. 29-45. W: „Kontrola i Ograniczanie Ryzyka Następstw Stosowania Środków Ochrony Roślin". Inst. Ochr. Roślin - PIB, Poznań, 101 ss.

Surawska M., Kołodziejczyk R. 2006. Zużycie środków ochrony roślin w Polsce. Prog. Plant Prot./Post. Ochr. Roślin 46 (1): $470-483$.

Ustawa z dnia 16 lutego 1961 r. o ochronie roślin uprawnych przed chorobami, szkodnikami i chwastami. Dz. U. 1961 Nr 10, poz. 55.

Ustawa z dnia 12 lipca 1995 r. o ochronie roślin uprawnych. Dz. U. $1995 \mathrm{Nr}$ 90, poz. 446.

Ustawa z dnia 18 grudnia 2003 r. o ochronie roślin. Dz. U. 2004 Nr 11, poz. 94.

Węgorek W. 1972. Program i potrzeby nowoczesnej ochrony roślin. Biul. Inst. Ochr. Roślin 52: 5-15.

Wolny S., Wolna D., Kazikowska H., Krawczyk D. 2010. Historia 50 Sesji Naukowych Instytutu Ochrony Roślin w liczbach. s. 25-40. W: ,50 lat Sesji Naukowych IOR (1961-2010)”. Inst. Ochr. Roślin - PIB, Poznań, 324 ss. 